\title{
The influence of physostigmine on visual-vestibular interaction in hereditary ataxias
}

\author{
CC TIJSSEN, $\dagger$ LJ ENDTZ, ${ }^{*}$ C GOOR $\dagger$ \\ From the Departments of Neurology* and Neurophysiology, $\dagger$ Municipal Hospital Leyenburg, The Hague, \\ The Netherlands
}

SUMMARY Visual suppression of caloric nystagmus was studied in five patients with hereditary ataxia before and after administration of physostigmine. All patients had an initial abnormal ocular fixation index that improved after physostigmine was given. The data indicate that there is a partly reversible disturbance of visual-vestibular interaction in patients with hereditary ataxia, caused by an impairment of a central cholinergic mechanism.

The hereditary ataxias constitute a number of degenerative cerebellar diseases having ataxia as their common feature. The pathophysiological basis underlying this group of disorders is unknown. Hereditary factors play an important role in their aetiology but sporadic cases also occur.' Recent studies have indicated a possible biochemical deficit. Primary or secondary abnormalities of pyruvate metabolism have been identified in up to $50 \%$ of unselected series of patients with hereditary ataxias, ${ }^{23}$ and in patients with Friedreich's ataxia a lowered activity of pyruvate oxidation caused by a defect at the level of the third component of the pyruvate dehydrogenase complex, that is the lipoamide dehydrogenase, has been demonstrated. ${ }^{4-6}$ This disturbance of the pyruvate metabolism leads to impaired production of acetylcoenzyme $A$ and subsequently to impaired synthesis of the neurotransmitter acetylcholine. ${ }^{26}$ Acetylcholine synthesis seems exquisitely sensitive to impaired pyruvate oxidation. ${ }^{3}$ Clinical studies have suggested that low doses of physostigmine, a centrally active cholinesterase inhibitor, improve signs of ataxia in patients with hereditary ataxias. ${ }^{7-4}$ Objective criteria to evaluate the influence of this drug are however lacking.

A number of ocular abnormalities occur in hereditary ataxias including nystagmus (especially gaze-evoked, rebound and downbeat nystagmus), impaired smooth pursuit, saccadic dysmetria and

Present address and address for reprint requests: Dr CC Tijssen, Department of Neurology, St. Elisabeth Hospital, P.O. Box 90151, 5000 LC Tilburg, The Netherlands.

Received 6 July 1984 and in revised form 6 November 1984 . Accepted 12 January 1985 defective visual suppression of vestibular nystagmus. ${ }^{10-12}$ The ability to suppress the vestibuloocular reflex (VOR) by fixation is a valuable indication of cerebellar pathology.12-15 There is evidence that the vestibulo-cerebellum, especially the flocculus, is an important site for this visualvestibular interaction that facilitates adaptive changes in the VOR. ${ }^{16-21}$

In this study we investigated the influence of the drug physostigmine on the visual suppression of caloric-induced vestibular nystagmus in five patients with hereditary ataxia.

\section{Material and methods}

Five patients with hereditary ataxia were studied, whose relevant data are summarised in the table. The patients used no drugs at the time of investigation. Each subject was examined with electro-nystagmography (ENG) equipment using a time constant of 5 seconds and a filter of $15 \mathrm{~Hz}(3 \mathrm{~dB})$. Horizontal eye movements were recorded with surface electrodes placed near the inner and outer canthus of both eyes. A voluntary eye movement over $20^{\circ}$ was used for calibration of the angular velocity of the slow phase of the nystagmus. Caloric stimulation was applied by irrigating both ears with $50 \mathrm{ml}$ of water at $30^{\circ} \mathrm{C}$ during 20 seconds with eyes closed. If no good response was obtained water at $15^{\circ} \mathrm{C}$ was also applied. With this procedure a maximum slow phase eye velocity occurs at about 45 seconds after the onset of irrigation and maintains for about 30 seconds. $^{25}$ The visual suppression test was carried out during this maximum intensity of caloric nystagmus at $55 \mathrm{sec}$ onds after the onset of irrigation. The patients were asked to open their eyes and fix their gaze upon a red spot light at a distance of $1 \frac{1 / 2}{2}$ metre for 15 seconds. Nystagmus frequency, amplitude and slow phase velocity, which was averaged over 10 wave forms, were measured before and after eye opening. The maximum response during visual 
fixation was selected. Visual suppression was quantified according to the ocular fixation index. This index is obtained by the slow phase velocity (SPV) of the nystagmus during ocular fixation (EO) divided by the SPV of the nystagmus with eyes closed (EC) according to the formula:

$$
\text { Ocular fixation index }=\frac{\text { SPV.EO }}{\text { SPV.EC }}
$$

Informed consent was obtained from the patients, and subsequently $1 \mathrm{mg}$ physostigmine was given intravenously. Fifteen minutes after the injection the test procedures were repeated with the same water temperature. To prevent any adaptation at least 30 minutes were taken between the caloric stimulations without and with physostigmine.

\section{Results}

With their eyes closed the caloric responses were bilaterally reduced in two patients, showing a maximum slow phase velocity of the nystagmus of $10^{\circ}$ and $12 \%$. The other three patients had normal slow phase velocities for post-caloric nystagmus with values ranging from 24 to $35 \%$. The ocular fixation indexes of the patients before and after administration of physostigmine are given in the table. In humans the ocular fixation index has an upper normal limit of approximately 0.5 .222425 All five patients had an abnormal ocular fixation index, ranging from 0.56 to $2 \cdot 00$. After intravenous physostigmine the ocular fixation index of the patients improved significantly ( $p<0.01$ on Student's $t$ test), patient 5 was even showing a completely normal ocular fixation index of 0 , which means a visual suppression of $100 \%$ (fig $1, \mathrm{~A}, \mathrm{~B}$ ). Caloric nystagmus and visual suppression before and after treatment of patient 3 are shown in fig 2 (A, B). It was noted that the greatest improvement occurred in the patients with shorter duration of their symptoms (patients 1,2 and 5). Intravenous physostigmine produced some excessive sweating in three, and abdominal discomfort in two of the five patients. These complaints disappeared within an hour and no special measures were needed.

\section{Discussion}

Some clinical studies have dealt with the beneficial effect of physostigmine in patients with hereditary ataxias. Low doses of this drug improved signs of ataxia in both short-term and long-term management of these patients. $^{7-y}$ The improvement was mainly determined by ataxia scores and videotape recording. We studied an objective parameter, that is the visual suppression of caloric nystagmus to evaluate the influence of physostigmine in five patients with hereditary ataxias. All five patients had an initial abnormal ocular fixation index that improved significantly after intravenous physostigmine (table); one patient even had a normal ocular fixation index after treatment. Two patients showed reduced responses after caloric stimulation with decreased slow phase velocity of the nystagmus Reduced vestibulo-ocular responses to caloriç stimulation have also been reported in previous cases of hereditary ataxias, especially in patients with Friedreich's ataxia." Three patients had anf ocular fixation index above 1.0 which means that the nystagmus was greater with eyes open than with eyes closed. This phenomenon is called paradoxica? response and has been reported in spinocerebellar

Table Summary of case histories in patients with hereditary ataxia and results of the administration of physostigmine on the ocular fixation index

\begin{tabular}{|c|c|c|c|c|c|c|c|c|}
\hline Case & Sex & Age (y) & Clinical features & $\begin{array}{l}\text { Duration of } \\
\text { symptoms }(y)\end{array}$ & $\begin{array}{l}\text { Family } \\
\text { history }\end{array}$ & $C T$ scan & $O F I^{*}$ & OFI \\
\hline 1 & $\mathbf{M}$ & 60 & $\begin{array}{l}\text { ataxia } \\
\text { dysarthria } \\
\text { hyperreflexia } \\
\text { heterochromia iris }\end{array}$ & 2 & - & $\begin{array}{l}\text { atrophy of pons and } \\
\text { cerebellum }\end{array}$ & $1 \cdot 09$ & 0.68 \\
\hline 2 & $\mathbf{M}$ & 66 & $\begin{array}{l}\text { ataxia } \\
\text { nystagmus } \\
\text { hyperreflexia } \\
\text { Babinski sign }\end{array}$ & 10 & + & atrophy of cerebellum & $2 \cdot 00$ & $1 \cdot 52$ \\
\hline 3 & $\mathbf{M}$ & 50 & $\begin{array}{l}\text { ataxia } \\
\text { dysarthria }\end{array}$ & 30 & + & $\begin{array}{l}\text { atrophy of pons and } \\
\text { cerebellum }\end{array}$ & $0 \cdot 76$ & $0 \cdot 61$ \\
\hline 4 & $\mathbf{M}$ & 70 & $\begin{array}{l}\text { ataxia } \\
\text { dysarthria } \\
\text { nystagmus } \\
\text { hyperreflexia }\end{array}$ & 23 & - & $\begin{array}{l}\text { atrophy of pons and } \\
\text { cerebellum }\end{array}$ & $1 \cdot 14$ & $0 \cdot 90$ \\
\hline 5 & $\mathbf{M}$ & 21 & $\begin{array}{l}\text { ataxia } \\
\text { nystagmus } \\
\text { Babinski sign } \\
\text { optic atrophy } \\
\text { muscle atrophy } \\
\text { slight neuropathy legs }\end{array}$ & 2 & + & $\begin{array}{l}\text { atrophy of pons and } \\
\text { cerebellum }\end{array}$ & 0.56 & 0 \\
\hline
\end{tabular}

OFI* = ocular fixation index before physostigmine

OFI $\dagger=$ ocular fixation index after physostigmine 
disease, ${ }^{14}$ posterior fossa lesions, ${ }^{22}$ brainstem lesions, ${ }^{26}$ altered states of consciousness ${ }^{27}$ and in brain damage after head injury. ${ }^{28}$ The underlying mechanism is not certain.

It is known that the visual suppression of vestibular nystagmus is often impaired in patients with cerebellar disease, including hereditary ataxias. ${ }^{11-142224}$ From experimental studies in animals it appears that this visual-vestibular interaction is mediated by the vestibulocerebellum, especially the cerebellar flocculus. ${ }^{16-1421}$ The vestibulocerebellum (flocculus, nodulus, ventral uvula and ventral paraflocculus) receives input from the VOR through mossy fibre projections from the ipsilateral vestibular nerve and the vestibular nuclei. ${ }^{1230}$ The Purkinje cells of the flocculus in turn project direct inhibitory axons to the ipsilateral vestibular nuclei, resulting in control over the VOR. ${ }^{1217182223}$ The afferent signals of the visual system can reach the cerebellar flocculus by two different pathways. Retinal signals can be transferred by the accessory optic tract and pretectal nuclei to the dorsal cap of the inferior olive, which acts as a final relay for the visual climbing fibre input to the flocculus. ${ }^{31-34}$ Another optic pathway, in which the superior colliculus and lateral reticular nucleus are probably involved but whose exact course still remains unknown, reaches the flocculus as a mossy fibre input. ${ }^{333536}$ Whether the climbing fibre pathway or the mossy fibre pathway is responsible for adjustment of the VOR has not been clearly established yet, but especially the mossy fibre pathway seems to be involved. ${ }^{35-37}$ Finally the cortical smooth pursuit system also plays an important role in the visual suppression of the VOR..$^{121315}$

Histochemical studies have shown high cholinergic activity in the inferior olive, especially in the dorsal cap, the brainstem reticular formation, the lateral reticular nucleus in particular, and the
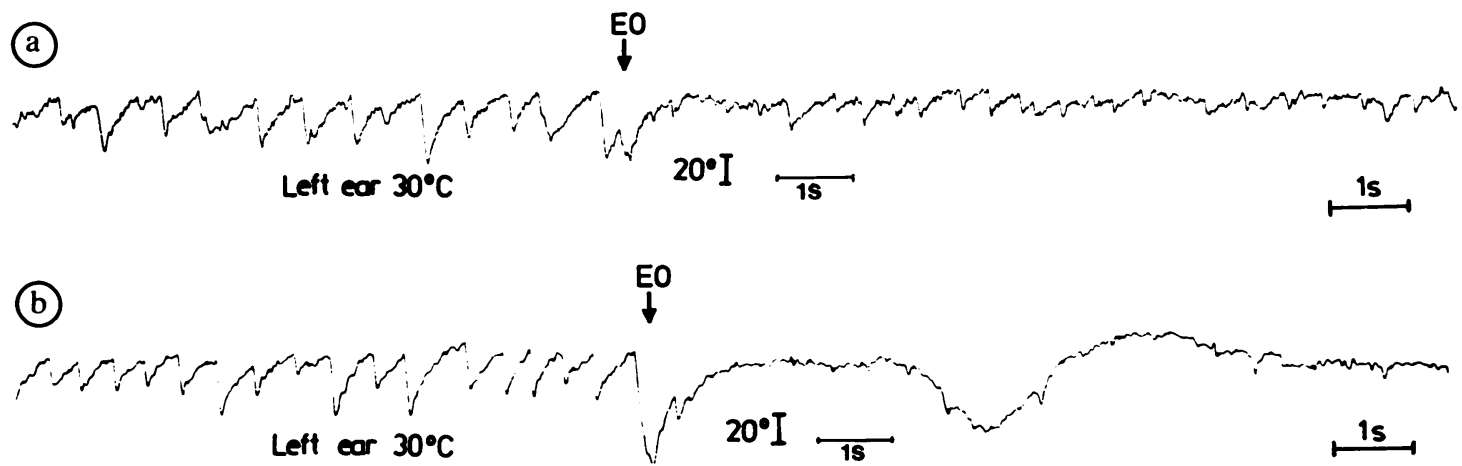

Fig 1 Caloric-induced vestibular nystagmus and visual suppression of case 5 before (A) and after (B) administration of physostigmine.

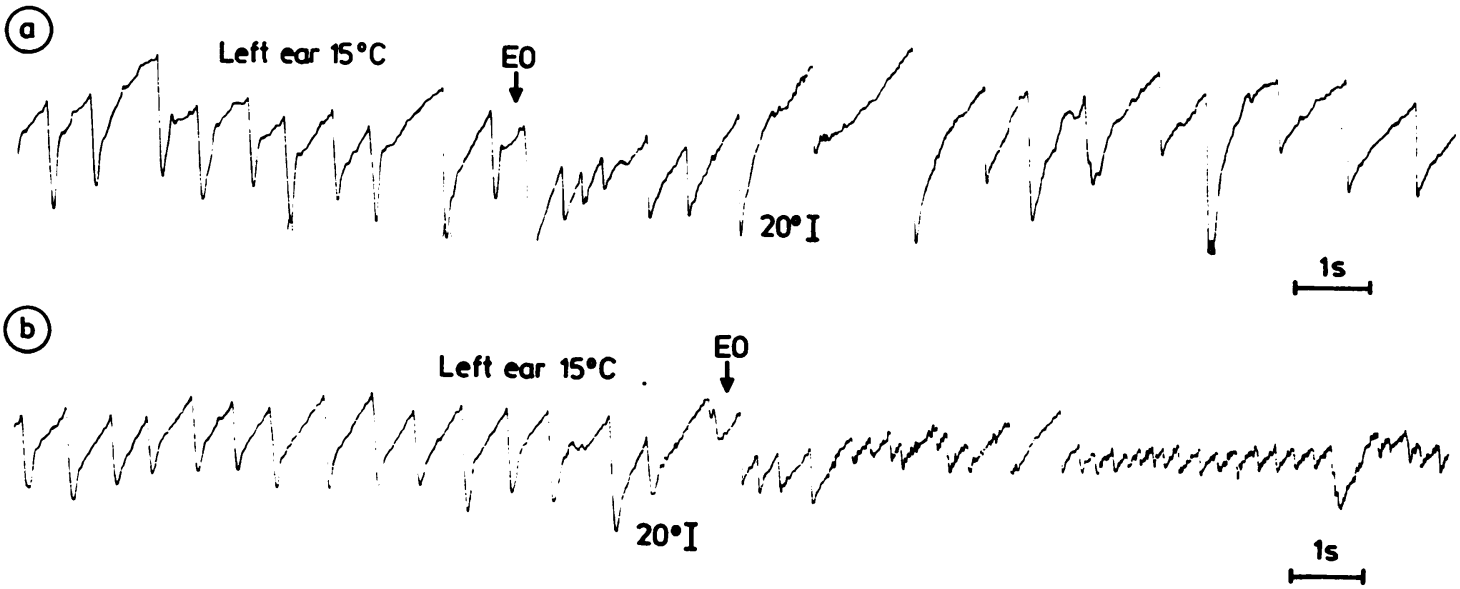

Fig 2 Caloric-induced vestibular nystagmus and visual suppression of case 3 before (a) and after (b) administration of physostigmine. This patient also shows the phenomenon of saccadic (futter) dysmetria. 
cerebral cortex. ${ }^{38-40}$ There is also evidence that the mossy fibre projections to the vestibulocerebellum have a cholinergic input. ${ }^{41} \mathrm{~A}$ reduced synthesis of acetylcholine, caused by a defect in the pyruvate metabolism, at any of these sites may result in a disturbance of visual-vestibular interaction and could account for the improvement of the ocular fixation indexes on physostigmine that we have seen in our patients. The results demonstrate that the disturbance of visual-vestibular interaction represented by the abnormal ocular fixation index is partly reversible. The improvement of the ocular fixation index was better in patients with shorter duration of symptoms, suggesting that irreversible processes appear in the course of time.

In conclusion, our study demonstrates that the visual suppression of vestibular nystagmus is disturbed in patients with hereditary ataxias. The impairment of visual-vestibular interaction is at least partly reversible and improves on intravenous physostigmine suggesting an acetylcholinergic disturbance. Further studies are required to investigate whether there is any relationship between the degree of improvement of the ocular fixation index and the beneficial effect of this drug on clinical symptoms in these patients.

The authors thank Dr TCAM van Woerkom for his helpful criticism and Mrs Joke van der Veeken for secretarial assistance.

\section{References}

' Gilman S, Bloedel JR, Lechtenberg R. Disorders of the Cerebellum. Contemporary Neurology Series, vol. 21. Philadelphia: FA Davis Company, 1981.

2 Blass JP. Disorders of pyruvate metabolism. Neurology (NY) 1979;29:280-6.

${ }^{3}$ Kark RAP, Rodriguez-Budelli M. Pyruvate dehydrogenase deficiency in spinocerebellar degenerations. Neurology (Minneap) 1979;29:126-31.

${ }^{4}$ Blass JP, Kark RAP, Menon NK. Low activities of the pyruvate and oxuglutarate dehydrogenase complexes in five patients with Friedreich's ataxia. New Engl J Med 1976;295:62-7.

${ }^{5}$ Kark RAP, Rodriguez-Budelli M. Clinical correlations of partial deficiency of lipoamide dehydrogenase. Neurology (Minneap) 1979;29:1006-13.

- Barbeau A. Pathophysiology of Friedreich's ataxia. In: Matthews WB, Glaser GH, eds. Recent advances in Clinical Neurology. New York: Churchill Livingstone, 1982:125-47.

${ }^{7}$ Kark RAP, Blass JP, Spence MA. Physostigmine in familial ataxias. Neurology (Minneap) 1977;27:70-2.

${ }^{8}$ Rodriguez-Budelli M, Kark RAP, Blass JP, Spence MA. Action of physostigmine on inherited ataxias. Adv Neurol 1978;21:195-202.

${ }^{y}$ Perlman SL, Kark RAP, Schlecter B, Budelli MR, Youkeles L. Preliminary studies of oral physostigmine in the long-term management of inherited ataxias. Neurology (Minneap) 1980;30:381-2.

${ }^{10}$ Zee DS, Yee RD, Cogan DC, Robinson DA, King Engel W. Ocular motor abnormalities in hereditary cerebellar ataxia. Brain 1976;99:207-34.

"Kirkham TH, Guitton D, Katsarkas A, Kline IB, Andermann E. Oculomotor abnormalities in Friedreich's ataxia. Can J Neurol Sci 1979; 6:167-72.

${ }^{12}$ Leigh RJ, Zee DS. The neurology of eye movement. Contemporary Neurology Series, Vol. 23. Philadelphia FA Davis Company, 1983.

${ }^{13}$ Dichgans J, Reutern GM von, Römmelt U. Impaired suppression of vestibular nystagmus by fixation in cerebellar and non-cerebellar patients. Arch Psychiat Nervenkr 1978;226:183-99.

14 Baloh RW, Jenkins HA, Honrubia V, Yee RD, Lau CGY. Visual-vestibular interaction and cerebellar atrophy. Neurology (Minneap) 1979;29:116-9.

${ }^{15}$ Chambers BR, Gresty MA. The relationship between disordered pursuit and vestibulo-ocular reflex suppression. J Neurol Neurosurg Psychiatry 1983;46:61-6.

${ }^{16}$ Takemori S, Cohen B. Loss of visual suppression of vestibular nystagmus after flocculus lesions. Brain Res 1974;72:213-24.

${ }^{17}$ Ito M. Functional specialisation of flocculus Purkinje cells and their differential localisation determined in connection with the vestibulo-ocular reflex. In: Bake $\bar{b}$ R, Berthoz A, eds. Control of Gaze by Brainstem Neurons. Amsterdam: Elsevier/North Hollan\& Biomedical Press, 1977:177-86.

${ }^{18}$ Ito M. Neuronal events in the cerebellar flocculus associo ated with an adaptive modification of the vestibuloocular reflex of the rabbit. In: Baker $R$, Berthoz $A$ O eds. Control of Gaze by Brainstem Neurons. Amster dam: Elsevier/North-Holland Biomedical Press 1977:391-8.

${ }^{14}$ Lisberger SG, Fuchs AF. Role of the primate flocculus in smooth pursuit eye movements and rapid behavioural modification of the vestibulo-ocular reflex. In: Baker R, Berthoz A, eds. Control of Gaze by Brainstem Neurons. Amsterdam: Elsevier/North-Holland Biomedical Press, 1977:381-9.

${ }^{20}$ Baloh RW, Yee RD, Kimm J, Honrubia V. Vestibuloocular reflex in patients with lesions involving the vestibulo-cerebellum. Exp Neurol 1981;72:141-52.

${ }^{21}$ Zee DS, Yamazaki A, Butler PH, Gücer G. Effects of ablation of flocculus and paraflocculus on eye movements in primate. $J$ Neurophysiol 1981;46:878-99.

22 Alpert JN. Failure of fixation suppression: a pathologic effect of vision on caloric nystagmus. Neurology (Minneap) 1974;24:891-6.

${ }^{23}$ Takemori S, Cohen B. Visual suppression of vestibular nystagmus in rhesus monkeys. Brain Res 1974;72:203-12.

${ }^{24}$ Demanes JP, Ledoux A. Automatic fixation mechanisms and vestibular stimulation. Adv Otorhinolaryngol 1970;17:90-8.

${ }^{25}$ Kato I, Kimura Y, Aoyagi M, Mizukoshi K, Kawasaki T. Visual suppression of caloric nystagmus in normal individuals. Acta Otolaryngol 1977;83:245-51.

${ }^{26}$ Korres S. Electronystagmographic criteria in neuro- 
otological diagnosis. J Neurol Neurosurg Psychiatry 1978;41:254-64.

${ }^{27}$ Maccario M, Backman JR, Korein J. Paradoxical caloric response in altered states of consciousness. Neurology (Minneap) 1972;22:781-8.

${ }^{28}$ Van Woerkom TCAM. Calorisch oculographisch onderzoek bij trauma capitis. Thesis, Groningen, The Netherlands, 1981.

${ }^{24}$ Sato Y, Kato I, Kawasaki T, Mizukoshi K, Hayano M. Failure of fixation suppression of caloric nystagmus and ocular motor abnormalities. Arch Neurol 1980;37:35-8.

${ }^{30}$ Dichgans J, Buettner UW. The vestibulo-ocular reflex. In: Lessell S, van Dalen JTW, eds. Neuroophthalmology, vol. 1. Amsterdam: Excerpta Medica 1980:178-96.

${ }^{31}$ Alley K, Baker R, Simpson JI. Afferents to the vestibulo-cerebellum and the origin of the visual climbing fibers in the rabbit. Brain Res 1975;98:5829.

${ }^{32}$ Maekawa K, Simpson JI. Climbing fiber response evoked in vestibulo-cerebellum of rabbit from visual system. J Neurophysiol 1973;36:649-66.

${ }^{33}$ Maekawa K, Takeda T. Electrophysiological identification of the climbing and mossy fiber pathways from the rabbit's retina to the contralateral cerebellar flocculus. Brain Res 1976;109:169-74.

${ }^{34}$ Maekawa K, Takeda T. Afferent pathways from the visual system to the cerebellar flocculus of the rabbit. In: Baker R, Berthoz A, eds. Control of Gaze by Brains- tem Neurons. Amsterdam: Elsevier/North-Holland Biomedical Press, 1977:187-97.

${ }^{35}$ Maekawa K, Takeda T. Mossy fiber responses evoked in the cerebellar flocculus of rabbits by stimulation of the optic pathway. Brain Res 1975;98:590-5.

${ }^{36}$ Kawasaki T, Kato I, Aoyagi M, Sato Y, Koike Y, Ino H. On the role of the brainstem in the visual suppression of caloric nystagmus. In: Hood JD, ed. Vestibular Mechanism in Health and Disease, VI extra-ordinary meeting of the barany society. London: Academic Press, 1978:247-53.

${ }^{37}$ Noda H. Visual mossy fiber inputs to the flocculus of the monkey. Ann NY Acad Sci 1981;374:465-75.

${ }^{38}$ Marani E, Voogd J, Boekee A. Acetylcholinesterase staining in subdivisions of the cat's inferior olive. $J$ Comp Neurol 1977;174:209-26.

${ }^{34}$ Rotter A, Birdsall NJM, Burgen ASV, Field PM, Hulme EC, Raisman G. Muscarinic receptors in the central nervous system of the rat. I. Technique for autoradiographic localisation of the binding of $(3 \mathrm{H})$ propyl benzilylcholine mustard and its distribution in the forebrain. Brain Res Rev 1979;1:141-65.

${ }^{40}$ Rotter A, Birdsall NJM, Field PM, Raisman G. Muscarinic receptors in the central nervous system of the rat. II. Distribution of binding of $(3 \mathrm{H})$ propylbenzylcholine mustard in the midbrain and hindbrain. Brain Res Rev 1979; 1:167-83.

${ }^{41}$ Kan KSK, Chao LP, Eng LF. Immunohistochemical localisation of choline acetyltransferase in rabbit spinal cord and cerebellum. Brain Res 1978;146:221-9. 